ORIGINAL ARTICLE

\title{
Comparing the behavioural thermoregulation response to heat stress by Atlantic salmon parr (Salmo salar) in two rivers
}

Emily Corey, 1,

Email emily.corey@unb.ca

Tommi Linnansaari, 2

Stephen J. Dugdale, 3

Normand Bergeron, 4

Jean-François Gendron, 5

Michel Lapointe, 5

Richard A. Cunjak, 2

AQ1

$\mathrm{AQ} 2$

1 Department of Biology, Canadian Rivers Institute, University of New Brunswick, Fredericton, New Brunswick, Canada

2 Department of Biology, Faculty of Forestry and Environmental Management, Canadian Rivers Institute, University of New Brunswick, Fredericton, New Brunswick, Canada

3 School of Geography, University of Nottingham, Nottingham, UK

4 Centre Eau Terre Environnement, Institute National de la Recherche Scientifique, Québec, Québec, Canada

5 Department of Geography, McGill University, Montreal, Québec, Canada

Correspondence

Emily Corey, Department of Biology, Canadian Rivers Institute University of New Brunswick, P.O. Box 4400, Fredericton, NB E3B 5A3, Canada.

Email: emily.corey@unb.ca

\section{Abstract}

Climate change is expected to increase the frequency and magnitude of extreme thermal events in rivers. The Little Southwest Miramichi River (LSWM) and the Ouelle River (OR) are two Atlantic salmon (Salmo salar) rivers located in eastern Canada, where in recent years, water temperatures have exceeded known thermal limits $\left(\sim 23^{\circ} \mathrm{C}\right)$. Once temperature surpasses this threshold, juvenile salmon exploit thermal heterogeneity to behaviourally thermoregulate, forming aggregations in 
coolwater refuges. This study aimed to determine whether the behavioural thermoregulation response is universal across rivers, arising from common thermal cues. We detailed the temperature and discharge patterns of two geographically distinct rivers from 2010 to 2012 and compared these with aggregation onset temperature. PIT telemetry and snorkelling were used to confirm the presence of aggregations. Mean daily maximum temperature in 2010 was significantly greater in the OR versus the LSWM $(p=0.005)$, but not in other years $(p=0.090-0.353)$. Aggregations occurred on 14 and 9 occasions in the OR and LSWM respectively. Temperature at onset of aggregation was significantly greater in the OR $\left(T_{\text {onset }}=28.3^{\circ} \mathrm{C}\right)$ than in the LSWM $\left(T_{\text {onset }}=27.3^{\circ} \mathrm{C} ; p=0.049\right)$. Logistic regression models varied by river and were able to predict the probability of aggregation based on the preceding number of hours $>23^{\circ} \mathrm{C}\left(R^{2}=0.61 \& 0.65\right.$; $\mathrm{P}_{50}=27.4^{\circ} \mathrm{C} \& 28.9^{\circ} \mathrm{C}$; in the OR and LSWM respectively). These results imply the preceding local thermal regime may influence behaviour and indicate a degree of phenotypic plasticity, illustrating a need for localised management strategies.

\section{Keywords}

Atlantic salmon
behavioural thermoregulation
heat stress
movement
thermal refuge
water temperature

\section{INTRODUCTION}

Climate change is predicted to significantly alter the distribution of aquatic organisms on a global scale, with water temperatures in some freshwater systems regularly approaching the upper lethal limit of many species (Caissie, 2006). Within eastern Canada, it is estimated that mean air temperature will increase by $2-6^{\circ} \mathrm{C}$ by the turn of the century (IPCC, 2014). There is little doubt that an air temperature increase of this magnitude will influence river temperatures (Swansburg, Chaput, Moore, Caissie, \& El-Jabi, 2002) and increase the frequency of extreme thermal events (Brodeur, Hébert, Caissie, \& Breau, 2015; IPCC, 2014). These deviations from historical thermal patterns are likely to influence distribution (Comte, Buisson, Daufresne, \& Grenouillet, 2013) and fundamental life history strategies of a diverse range of fishes (see: Crozier \& Hutchings, 2013; Jonsson \& Jonsson, 2009). Habitat heterogeneity is a physical characteristic that is often exploited by riverine organisms to mitigate the effects of climate change during key points in the year (Jonsson, 1989; Lytle \& Poff, 2004; Schlosser, 1991). Thermal anomalies can provide crucial habitat during periods of both heat stress (Kaya, Kaeding, \& Burkhalter, 1977; Mundahl, 1989; Snucins \& Gunn, 1995) and cold stress (Brown, Stanislawski, \& Mackay, 1993; Cunjak \& Power, 1986; Gibbons \& Sharitz, 1981; Peterson \& Rabeni, 1996) for many freshwater fishes. In recent decades, the importance of thermal patchiness as a moderator for the adverse effects of climate change has been increasingly acknowledged for a multitude of species, many of which live in environments that border their range of thermal tolerance, such as the salmonids (Armstrong, Ward, Schindler, \& Lisi, 2016; Isaak, Young, Nagel, Horan, \& Groce, 2015; Torgersen, Price, Li, \& McIntosh, 1999). 
Once water temperature approaches the upper incipient lethal temperature $\left(27.8^{\circ} \mathrm{C}\right.$; Elliott, 1991), juvenile salmonids will exhibit behavioural thermoregulation by abandoning their territories to seek out cool water refuges. This behaviour is commonly referred to as an aggregation response (Breau, Cunjak, \& Bremset, 2007). Behavioural thermoregulation has been observed in juvenile Atlantic salmon at a variety of temperatures but is most commonly associated with water temperatures approaching specific thermal limits. For example, Atlantic salmon parr have been observed to relocate from feeding territories into cooler water refuges when water temperatures have exceeded $22-23^{\circ} \mathrm{C}$ in the Miramichi River, New Brunswick, Canada (Breau et al., 2007; Cunjak et al., 1993, 2005; Gibson, 1966). Although some variability exists, these temperatures coincide with published thresholds for the onset of thermal stress $\left(22-24^{\circ} \mathrm{C}\right.$, Breau, Cunjak, \& Peake, 2011; Lund, Caissie, Cunjak, Vijayan, \& Tufts, 2002) and the reduction in feeding behaviour in parr $\left(22-24^{\circ} \mathrm{C}\right.$; Elliott, 1991). A review by Elliott and Elliott (2010) concluded that the upper thermal limit for survival (7 days with a 50\% survival rate) in juvenile Atlantic salmon ranged from 22 to $28^{\circ} \mathrm{C}$, with $\sim 22.5^{\circ} \mathrm{C}$ representing the upper temperature limit for growth (see: Elliot \& Hurley, 1997; Grande \& Andersen, 1991; Jonsson, Forseth, Jensen, \& Næsje, 2001; Lund et al., 2002). Despite some variability in thermal thresholds for behaviour and physiology, the physiological mechanism behind thermally induced territory abandonment remains largely unknown.

Most of the aforementioned temperature thresholds were determined using a single study population and/or a constant acclimation temperature in the laboratory. The potential influence of river temperature variability (thermal history) on the initiation of the aggregation response is therefore inherently disregarded. If thermal stress occurs in juvenile Atlantic salmon when temperatures exceed $23^{\circ} \mathrm{C}$, we expect that behavioural thermoregulation, in the form of aggregations within thermal refuges, will arise due to the presence of a single thermal cue regardless of the river and its particular thermal regime. As a result, the objective of this study was to establish whether predetermined thresholds of behavioural thermoregulation (thermal stress) are similar between populations in two eastern Canadian rivers with variable (and stressful) thermal regimes.

\section{MATERIALS AND METHODS}

\subsection{Study areas}

\subsubsection{Little Southwest Miramichi River, New Brunswick}

The Little Southwest Miramichi River (LSWM) is one of the largest branches of the Miramichi River, located in New Brunswick, Canada (Figure 1), with a catchment of $1,190 \mathrm{~km}^{2}$ (Hebert, Caissie, Satish, \& El- Jabi, 2011) representing $14.5 \%$ of the accessible rearing area for juvenile Atlantic salmon (Amiro, 1983). The LSWM is a sixth-order stream that is approximately $60-80 \mathrm{~m}$ in width and has an approximate depth of $0.55 \mathrm{~m}$ and flow of $34.1 \pm 0.57 \mathrm{~m}^{3} / \mathrm{s}$ at mean annual discharge (MAD) and a cobble/small cobble substrate (Modified Wentworth Scale; Wentworth, 1922). It is common for summer water temperatures in the LSWM to exceed biological thresholds of $22-23^{\circ} \mathrm{C}$ for juvenile Atlantic salmon (Caissie, Breau, Hayward, \& Cameron, 2012; Caissie, Satish, \& El-Jabi, 2007; Cunjak, Linnansaari, \& Caissie, 2013) and in recent years (2003-2005, 2010 and 2012), to occasionally surpass the upper critical temperature for survival of $27-28^{\circ} \mathrm{C}$ (Elliott \& Elliott, 2010). 


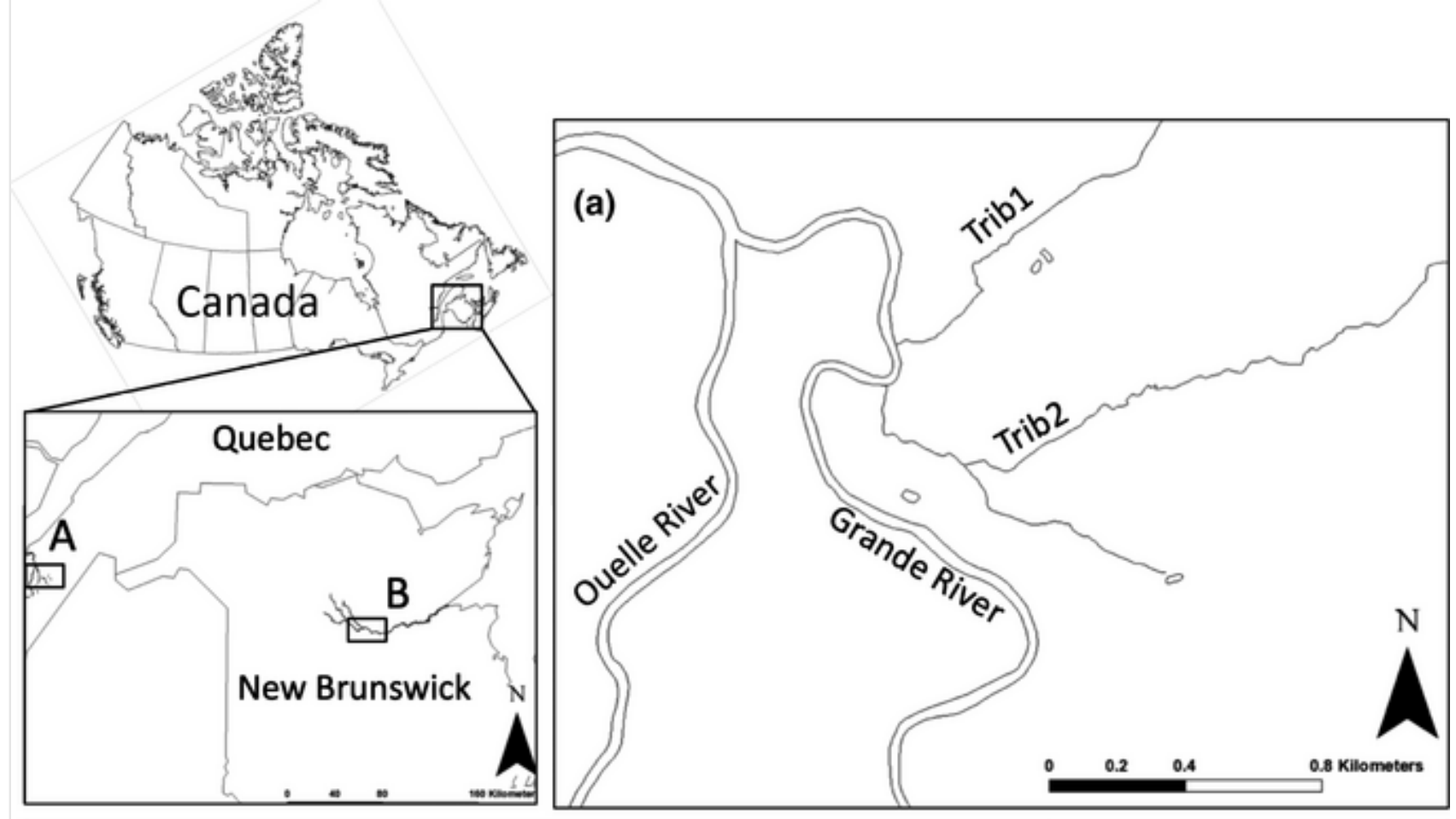

(b)

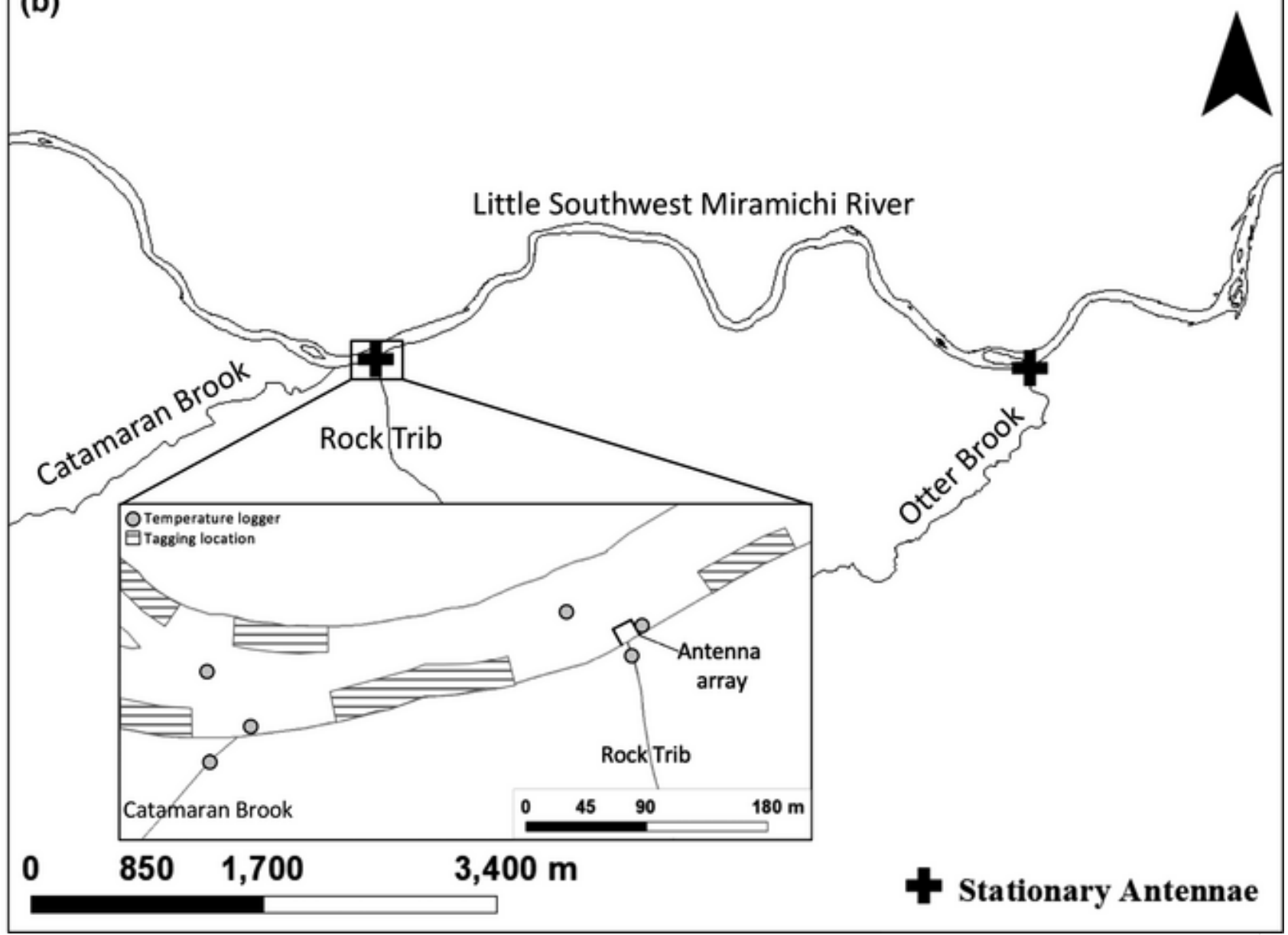

Fig. 1 Map of site locations in two Atlantic salmon rivers in Eastern Canada and (a) location of tributary-sourced cool water refuges encompassed by stationary Passive Integrated Transponder (PIT) antennae (+) in (a) la Grande River, QC, a contributing tributary to the Ouelle River (OR) containing two known thermal refuges, Trib1 (T1) \& Trib2 (T2); and in (b) the Little Southwest Miramichi River (LSWM), NB. Inset: a schematic of the Catamaran Brook site (CBK), showing the typical stationary PIT array 
and temperature logger $(\bullet)$ set-up common to all sites across both rivers. Shaded areas indicate typical PIT tagging and release areas in the LSWM

To assess specific frequency of, and conditions leading to, behavioural thermoregulation (i.e. juvenile salmon aggregations in cold water refuges), two 950$\mathrm{m}$ reaches of the LSWM, each containing a known thermal refuge tributary, Catamaran Brook (CBK) and Otter Brook (OBK), were chosen as study areas (Figure 1). $\mathrm{CBK}$ is a third-order tributary (mean width $7.2 \mathrm{~m}$; daily $T_{\text {mean }} \pm S E=17.08 \pm 0.25^{\circ} \mathrm{C} \& T_{\max }=19.17 \pm 0.29^{\circ} \mathrm{C}$ throughout 2010 study period $)$, located $25 \mathrm{~km}$ upstream from the mouth of the LSWM. Within the CBK study reach, a second known thermal refuge tributary is located $280 \mathrm{~m}$ downstream from the mouth of CBK, hereafter referred to as Rock Tributary (RT; i.e. daily $T_{\text {mean }}=15.03 \pm 0.18^{\circ} \mathrm{C}$ $\& T_{\text {max }}=17.49 \pm 0.23^{\circ} \mathrm{C}$ ) throughout the 2010 study period). OBK is a second-order tributary that is strongly influenced by deep aquifer groundwater discharge (i.e. daily $T_{\text {mean }}=16.88 \pm 0.21^{\circ} \mathrm{C} \& T_{\text {max }}=18.99 \pm 0.23^{\circ} \mathrm{C}$ throughout 2010 study period; Kurylyk, MacQuarrie, \& Voss, 2014) and is located approximately $6.7 \mathrm{~km}$ downstream from CBK.

\subsubsection{Ouelle River, Quebec}

The Ouelle River drains into the St Lawrence River estuary $\sim 150 \mathrm{~km}$ northeast of Quebec City, Quebec, Canada (Figure 1). It is a sixth-order river with a catchment area of $\sim 796 \mathrm{~km}^{2}$ (Gendron, 2013) and a MAD of $15.9 \pm 1.3 \mathrm{~m}^{3} / \mathrm{s}$, containing one major tributary, the Grande River, which joins the Ouelle River 25 river km from the confluence with the St Lawrence. The Ouelle River has a relatively stable population of Atlantic salmon (DFO, 2015). Like the LSWM, it is common for water temperatures within the Grande River and the Ouelle River to surpass thresholds of thermal stress for juvenile Atlantic salmon, with water temperatures $>27-28^{\circ} \mathrm{C}$ occurring often in recent years (2010-2012; Dugdale et al., 2016; Gendron, 2013). A $\sim 2,400 \mathrm{~m}$ reach of the Grande River was selected as a study site and included two second-order cool tributaries (T1 and T2; daily $T_{\text {mean }} \pm S E$ of $\mathrm{T} 1=16.77 \pm 1.56^{\circ} \mathrm{C} \&$ $T_{\max }=18.91 \pm 1.58^{\circ} \mathrm{C} ; \mathrm{T} 2 T_{\text {mean }} \& T_{\max }=17.00 \pm 2.36^{\circ} \mathrm{C} \& 17.34 \pm 2.60^{\circ} \mathrm{C}$ throughout 2010 study period) located near the confluence with the Ouelle River (Figure 1). These tributaries are known to attract aggregations of salmon parr during periods of thermal stress (Gendron, 2013). Mean river width of the Grande River in the study site is $\sim 23 \mathrm{~m}$, with a depth of $\sim 0.5 \mathrm{~m}$ and a coarse pebble-cobble substrate (Dugdale et al., 2016). This study area will be referred to as the Ouelle River (OR) throughout the remainder of the manuscript.

\subsection{Electrofishing and PIT tagging}

In 2010, a total of 240 ( $n=120$ per reach) $1+$ and $2+$ parr were captured and tagged within the two study areas within the LSWM (Figure 1b) from June 8 to 14, using modified $11 \mathrm{~mm}$ wedge $(0.3 \mathrm{~g}$; T. Linnansaari et al., unpublished data) or commercial $13 \mathrm{~mm}(0.6 \mathrm{~g})$ half-duplex Passive Integrated Transponder (PIT) tags (Texas Instruments RI-TRP-W9WK and RI-TRP-WRHP respectively). Parr were captured using a backpack electrofisher (Smith-Root LR-24) from five tagging locations in the Catamaran Brook study reach and from four locations in the OBK reach (Figure 1b). Fish were anaesthetised in a 40-ppm clove oil solution, and PIT tags were 
surgically implanted into the abdominal cavity. Only parr $>80 \mathrm{~mm}$ were tagged to maximise the survival rate of tagged fish (Sigourney, Horton, Dubreuil, Varaday, \& Letcher, 2005). Forklength and wet weight (g) were measured on all captured parr and tallied by site. Mean forklength and weight were $91.6 \pm 11.2 \mathrm{~mm}$ and $8.6 \pm 3.8 \mathrm{~g}$, respectively, with a mean tag weight to body weight ratio of 0.073 .

Electrofishing within the OR study reach was conducted in both 2011 and 2012. In 2011, a backpack electrofisher (Smith-Root 15c) was used to capture 166 parr within a $1 \mathrm{~km}$ radius of T1 and T2 from June 22 to 24. In 2012, from June 1 to 14 , a further 293 Atlantic salmon parr were captured from nine evenly spaced locations also located within a $\sim 1 \mathrm{~km}$ radius of $\mathrm{T} 1 / \mathrm{T} 2$. Parr captured in both years were tagged using 13-mm and 11-mm PIT tags using a similar protocol to that used in the LSWM. Mean $\pm S D$ forklength and weight measured $94.6 \pm 12.8 \mathrm{~mm}$ and $11.3 \pm 12.0 \mathrm{~g}$ and $104.4 \pm 10.8 \mathrm{~mm}$ and $15.2 \pm 5.4 \mathrm{~g}$ in 2011 and 2012 , respectively, with a mean tag weight to body ratio of 0.04 in 2011, and 0.03 in 2012. For a more detailed description of the tagging procedure in 2012, see Dugdale et al. (2016).

\subsection{Antenna set-up and PIT tag monitoring}

In 2010, three PIT antennae (single or double wire loop; stranded, gauge 10 copper wire; 5-10 $\mathrm{m}$ in width) were set up encompassing thermal plumes at each of the mouths of RT and OBK in the CBK and OBK study reaches (Figure 1b Inset). Each set of antennae was configured to detect directionality of entry into the plume (i.e. fish entering from up- or downstream direction, or, entering from the middle parts of the channel). A fourth antenna was added to the OBK configuration to detect movement into the OBK tributary. Antennae were tuned to resonance (Texas Instruments Antenna Tuning Indicator RI-ACC-008B) and connected to a $134.2 \mathrm{kHz}$ half-duplex reader/controller board (Texas Instruments Series 2000 reader system, RI-RFM-008B, RI-RFM-MB2A) via a four-channel multiplexer module (Texas Instruments RI-MOD-TX8A) set to $50 \mathrm{~ms}$ charge and listen times, resulting in 10 scans per second. A reader system was coupled to a data logger board (Oregon RFID) that recorded individual PIT tag number, date, time and antennae code within an approximate 1-m range of the antennae. PIT antennae were active June 27-August 10 throughout the summer of 2010 in the LSWM. Within the LSWM, active tracking, using a backpack PIT-detection unit (Linnansaari, Roussel, Cunjak, \& Halleraker, 2007) and a modified 2-person antenna (Linnansaari \& Cunjak, 2007), was used to determine the location of tagged fish prior to the onset of aggregation events and throughout aggregation events to locate presence of tagged fish within the trailing plume not encompassed by the stationary antennae.

Four antennae in a square configuration were assembled to encompass the cool water plume of both T1 and T2 within the OR in 2011; antennae were operational from June 21 to August 27. In 2012, two antennae were placed in each of T1 and T2, one at the mouth within the cool water thermal plume and another $5 \mathrm{~m}$ upstream to establish movement direction into tributaries during periods of heat stress. Antennae were operational from 12 June to 28 August 2012. For a full description of antennae configuration in 2012, see Dugdale et al. (2016).

\subsection{PIT-enabled aggregation detection}


We used PIT detection data to characterise the timing and duration of fish aggregation responses triggered by thermal events in the LSWM in 2010, and in 2011 and 2012 in the OR. Using this method, an aggregation was classified as the detection of $\geq 2$ unique PIT codes within a brief ( $\leq 1 \mathrm{hr}$ ) period of time. It was stipulated that these detections must occur throughout the warming period of the day $(\sim 7: 00-17: 00 \mathrm{hr})$ in the study rivers to eliminate fish detections observations that might not represent high temperature-driven movements, that is diurnal movement (Gries, Whalen, Juanes, \& Parrish, 1997; Thorpe, Morgan, Pretswell, \& Higgins, 1988), or discharge-related refuge (Dugdale et al., 2016; Puffer et al., 2015). This number was chosen as it was above the average PIT count of those individuals residing within proximity of the antennae and corresponded to visual surveys during select high-temperature events wherein large aggregations (i.e. $>10$ individuals) were observed, yet only two tagged fish were recorded. Aggregations typically comprised substantially more individuals than those detected by the PIT antennae, and for this reason, the detection of PIT tags was used as a proxy to identify the timing of an aggregation response but are not indicative of the strength of the response. As PIT equipment was not deployed in the LSWM throughout 2011 and 2012, aggregation presence was determined solely through snorkelling survey and was used to supplement PIT data in 2010. Similarly, aggregations were determined by snorkel survey throughout 2010 in the OR (Gendron, 2013), and by PIT detection in 2011 and 2012.

\subsection{Visual snorkelling surveys of fish aggregations}

In addition to the PIT tag data, we conducted visual surveys to characterise the timing and duration of fish aggregation responses triggered by thermal events in the LSWM in 2010, 2011 and 2012, and in 2010 and 2011 in the OR. Snorkelling surveys were conducted within thermal plumes and the main river at all sites to determine behaviour of juvenile salmon prior to, and throughout, thermal events. This style of visual survey is recognised as an effective method of quantifying fish presence and behaviour (Johnson et al., 2007), while minimising disturbance and risk of injury in comparison to other survey methods, such as electrofishing or seine netting. Snorkelling surveys were conducted in the LSWM by swimming upstream within main-stem reaches and within thermal plumes (CBK, RT and OBK). Similar snorkelling surveys took place in the OR (main stem and within thermal plumes of T1 and T2). Presence/absence of aggregation, species identification, age class, fish count and water temperature were recorded. A visual confirmation of an aggregation was classified as a group of $\geq 5$ parr within $1 \mathrm{~m}^{2}$. When an aggregation of Atlantic salmon was observed, number of fish, estimated age class and location were noted. In the LSWM, surveys to determine the presence/absence of aggregation were conducted throughout the warming period of the day until water temperatures began to cool $(\sim 7: 00-17: 00)$ when air temperature was forecasted to be $>25^{\circ} \mathrm{C}$ and water level was $<1.4 \mathrm{~m}$ (Environment Canada Station ID 01BP001).

\subsection{Temperature and discharge data collection}

In the LSWM, Onset Hobo Pendent ${ }^{\circledR}$ temperature loggers (accuracy $\pm 0.53^{\circ} \mathrm{C}$ ) were fixed within perforated PVC piping and anchored in place by use of a cinderblock. A total of nine loggers were set to read at 15-min intervals and placed within all study tributaries, thermal plumes and within the LSWM main stem in both reaches (e.g. see Figure 1b inset); loggers were active from May to September in all study years. Daily discharge data for the LSWM were obtained from the Environment Canada gauge 
station (Environment Canada Station ID 01BP001), located $21 \mathrm{~km}$ downstream from the OBK reach.

In the OR, 2010 temperature data were collected by inserting Maxim iButton data loggers (model DS1922L) into pressure-treated wood stakes. iButton loggers were inserted into holes lined with silicone rubber, then sealed into the stake with duct tape. Stakes were attached to veneer plates, deployed and were fixed in place using large boulders (Gendron, 2013). In 2011 and 2012, temperature was measured by use of 14 Onset Hobo loggers placed at regular intervals throughout the 2.4-km OR study reach. Each logger was assembled within PVC piping and weighted in a similar fashion to those in the LSWM with two loggers placed within the tributaries in conjunction with antennae placement. Discharge measurements were taken from an Environment Canada gauging station (Environment Canada Station ID 02PG022), located approximately $4.7 \mathrm{~km}$ downstream in the main-stem Ouelle River.

\subsection{Statistical analyses}

To compare environmental characteristics (mean and maximum daily temperature and mean daily discharge) between rivers, years and days with or without aggregations, a linear model one-way or two-way analysis of variance (ANOVA) was conducted. When analysing temperatures on days with versus days without aggregation, we used mean and maximum temperatures of " $x$ " days leading up to " $y$ " aggregation days. This method was selected to assess why an aggregation might occur on certain days as opposed to the days leading up to that aggregation. In case of a significant interaction between river and year, a subsequent Tukey post hoc test was conducted to discern differences between variables. When appropriate, data were log-transformed to meet the assumptions of normality and homoscedasticity. In all cases, $\alpha=0.050$ and values were expressed as mean \pm standard error of the mean $(S E M)$.

Area under the curve (AUC) was used to assess the measurable variance in diel thermal pattern. AUC was calculated for the period of time leading up to the first aggregation event to the final day where aggregations were noted in either river in 2010 and 2012 (June 27-August 8). These dates were selected not only due to the presence of aggregations, but also to mitigate any effect of decreasing daylight hours. As we were interested in the differences in thermal patterning between rivers, data were pooled by river across years and a paired sample $t$ test was run for all 31 days throughout the month of July to determine significance between AUC of the rivers (LSWM or OR) on individual days.

Behavioural thermoregulation is not expected to follow a normal distribution, and thus, a nonparametric test is more appropriate for assessing statistical significance. Temperature when an aggregation response was first observed by either visual survey or PIT detection will hereafter be referred to as "onset temperature" $\left(T_{\text {onset }}\right)$. As both methods were applied in the LSWM in 2010, a paired $t$ test was used to address any potential implications that might arise from exercising two data collection techniques $\left(t_{2}=0.6 ; p=0.576\right)$. Between river $T_{\text {onset }}$ was tested using a Mann-Whitney $U$ test and exact $p$-value, chosen for its robustness when handling small and unequal sample sizes (Ruxton, 2006). Probability of aggregation occurrence with number of hours exceeding $23^{\circ} \mathrm{C}$ was analysed using a binomial logistic regression. Logistic model fit was examined by using McFadden's pseudo- $R^{2}$. All data were analysed using $\mathrm{R}$ 
statistical software (R Development Core Team, 2016). In all instances, $\alpha=0.050$ and unless otherwise stated, values are expressed as mean $\pm S E M$. Thermal and observational data were collected from June 27 to August 26 in both rivers for all years. Data for July 6-9 and August 15 in 2010 were excluded from aggregation analyses in the OR because presence-absence of aggregations could not be confirmed. Due to our broader interest in overall differences between the rivers, the onset of aggregation data was pooled across years for statistical analyses.

\section{RESULTS}

\subsection{Temperature and discharge conditions}

Summer daily mean water temperature $\left(T_{\text {mean }}\right)$ in the LSWM varied significantly between years $(F=56.3, p<0.001)$, with $2011 T_{\text {mean }}$ being cooler than either 2010 or 2012 (Table 1), while 2010 and 2012 were not significantly different from one another $(p=0.93)$. A similar trend was observed in the OR, where $T_{\text {mean }}$ in 2011 $\left(19.9 \pm 0.4^{\circ} \mathrm{C}\right)$ was significantly cooler than $2010(21.9 \pm 0.1 ; p<0.001)$ and 2012 $\left(21.3 \pm 0.7^{\circ} \mathrm{C} ; p=0.002\right.$; Table 1$)$. OR $T_{\text {mean }}$ did not differ between 2010 and 2012 $(p=0.320)$. Summer daily mean water temperature did not significantly differ between the two rivers $(F=0.6, p=0.440)$.

\section{Table 1}

Summer water temperature and stream discharge variables of the Little Southwest Miramichi River (LSWM) and the Ouelle River (OR) for 2010-2012. Data were collected from June 27 to August 26 in all years. All values represent daily mean $\pm S E M$ derived from hourly maximum $\left(T_{\max }\right)$ and minimum $\left(T_{\min }\right)$ temperature, the mean diel fluctuation in temperature $\left(T_{\text {range }}\right)$ and mean summer discharge (MSD)

\begin{tabular}{|c|c|c|c|c|c|c|c|}
\hline \multirow{2}{*}{$\begin{array}{l}\text { Daily } \\
\text { variable }\end{array}$} & \multirow[t]{2}{*}{ Units } & \multicolumn{2}{|c|}{ Mean (all years) } & \multicolumn{3}{|c|}{ Mean LSWM } & \multirow{2}{*}{ 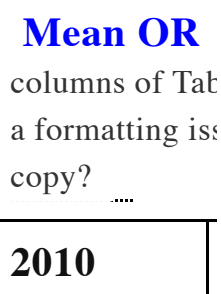 } \\
\hline & & LSWM & OR & 2010 & 2011 & 2012 & \\
\hline$T_{\max }$ & ${ }^{\circ} \mathrm{C}$ & $23.3 \pm 0.2$ & $24.2 \pm 0.3$ & $23.9 \pm 0.4$ & $21.9 \pm 0.2$ & $24.2 \pm 0.3$ & $25.5 \pm 0.4$ \\
\hline$T_{\min }$ & ${ }^{\circ} \mathrm{C}$ & $18.7 \pm 0.2$ & $18.4 \pm 0.2$ & $19.0 \pm 0.3$ & $17.9 \pm 0.2$ & $19.2 \pm 0.4$ & $18.9 \pm 0.4$ \\
\hline$T_{\text {range }}$ & ${ }^{\circ} \mathrm{C}$ & $4.6 \pm 0.1$ & $5.8 \pm 0.2$ & $4.9 \pm 0.2$ & $4.0 \pm 0.2$ & $4.9 \pm 0.2$ & $6.5 \pm 0.3$ \\
\hline$T_{\text {mean }}$ & ${ }^{\circ} \mathrm{C}$ & $20.9 \pm 0.1$ & $21.2 \pm 0.2$ & $21.4 \pm 0.3$ & $19.8 \pm 0.2$ & $21.5 \pm 0.3$ & $21.9 \pm 0.1$ \\
\hline MSD & $\mathrm{m}^{3} / \mathrm{s}$ & $21.8 \pm 1.3$ & $6.1 \pm 0.7$ & $13.6 \pm 0.8$ & $32.2 \pm 2.4$ & $19.5 \pm 2.6$ & $2.7 \pm 0.3$ \\
\hline
\end{tabular}

Mean maximum summer water temperature $\left(T_{\max }\right)$ differed significantly between rivers in $2010\left(\mathrm{LSWM}=23.9 \pm 0.4^{\circ} \mathrm{C} ; \mathrm{OR}=25.5 \pm 0.4^{\circ} \mathrm{C} ; F=8.313, p=0.005\right)$, but did not differ significantly in $2011\left(\mathrm{LSWM}=21.9 \pm 0.2^{\circ} \mathrm{C}, \mathrm{OR}=22.6 \pm 0.3^{\circ} \mathrm{C}\right.$; $F=15.1, p=0.09)$ or $2012\left(\mathrm{LSWM}=24.2 \pm 0.3^{\circ} \mathrm{C}, \mathrm{OR}=24.6 \pm 0.4^{\circ} \mathrm{C} ; F=0.9\right.$, $p=0.353$; Table 1). Absolute $T_{\max }$ in the LSWM occurred on July $8\left(30.6^{\circ} \mathrm{C}\right)$, July 18 $\left(25.5^{\circ} \mathrm{C}\right)$ and August $4\left(28.8^{\circ} \mathrm{C}\right)$ in 2010,2011 and 2012 respectively (Figure 2). Absolute $T_{\max }$ in the OR occurred on 7 July $2010\left(32.3^{\circ} \mathrm{C}\right)$, 16 July $2011\left(28.2^{\circ} \mathrm{C}\right)$ and 
2 August $2012\left(30.5^{\circ} \mathrm{C}\right)$, exceeding $T_{\max }$ measured in the LSWM in all 3 years (Figures 2 and 3).

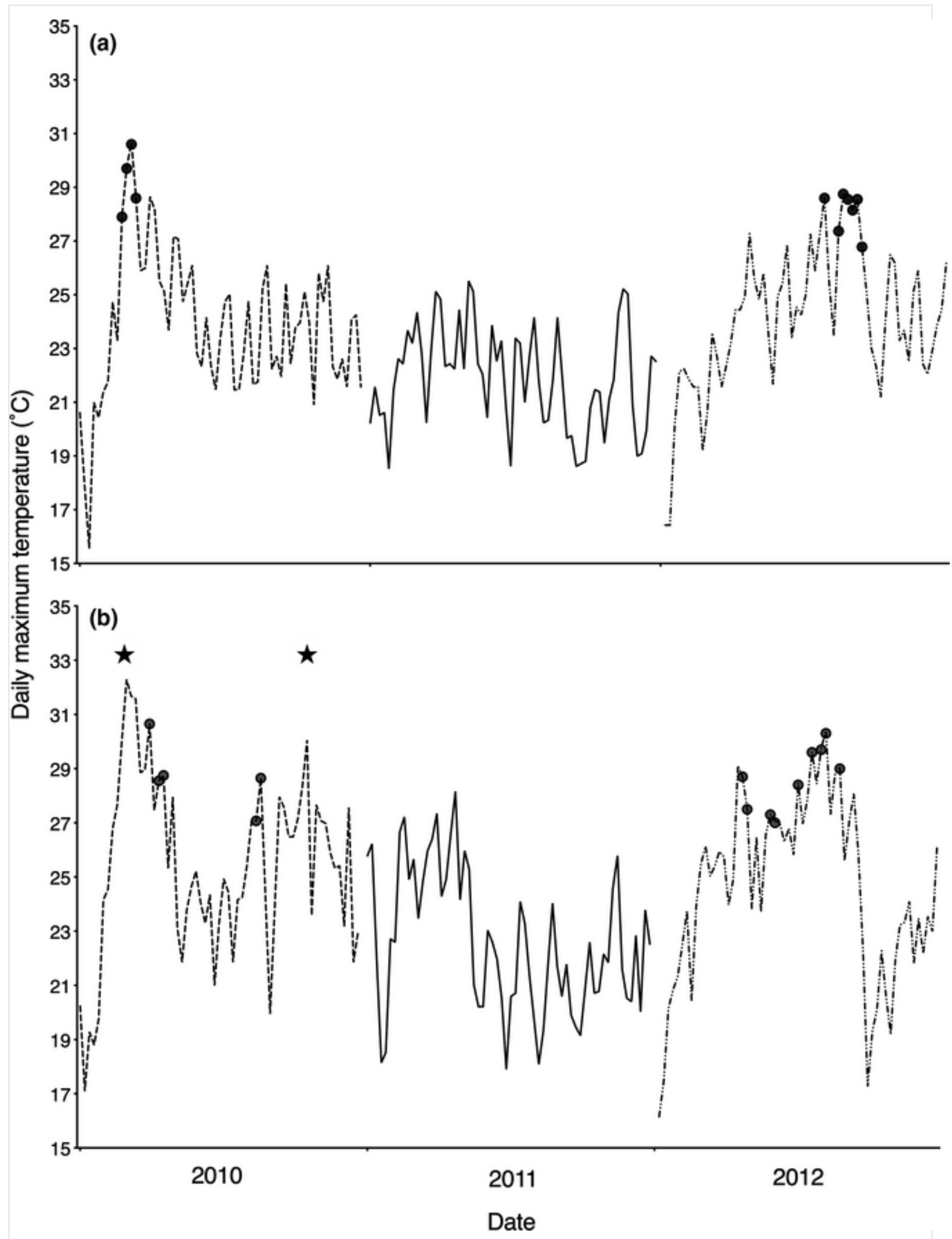

Fig. 2 Daily maximum temperature in (a) the Little Southwest Miramichi River (LSWM); and (b) the Ouelle River (OR) throughout the study period (June 27-August 26) in 2010, 2011 and 2012. Symbols (•) indicate days where aggregations occurred in each river; $\theta$ stars indicate days that were excluded from aggregation analysis (6-9 July 
and 15 August 2010 within the OR) as presence-absence of aggregation could not be confirmed

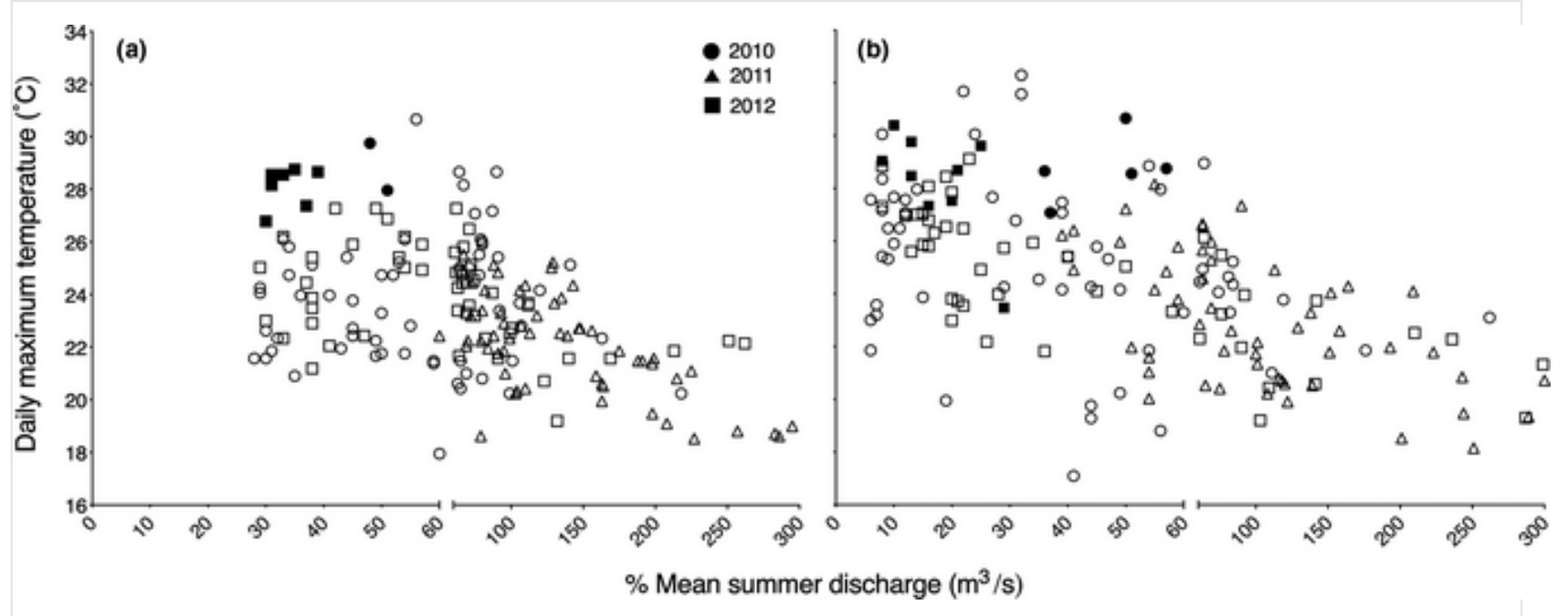

Fig. 3 Aggregation onset in relation to daily maximum water temperature $\left({ }^{\circ} \mathrm{C}\right)$ and mean summer discharge (MSD) from June 27 to August 26 (2010-2012) in (a) the Little Southwest Miramichi River (LSWM), NB; and (b) the Ouelle River (OR), QC. Closed symbols represent days where the onset of an aggregation was observed, while open symbols are days where no aggregations were present. MSD was $21.8 \pm 1.3 \mathrm{~m}^{3} / \mathrm{s}$ in the LSWM from 2010 to 2012 , and $6.1 \pm 0.7 \mathrm{~m}^{3} / \mathrm{s}$ in the OR

Within-river mean summer discharge varied greatly by year in the LSWM, with 2011 $\left(32.2 \pm 2.4 \mathrm{~m}^{3} / \mathrm{s}\right)$ having a significantly greater discharge than $2010\left(13.6 \pm 0.8 \mathrm{~m}^{3} / \mathrm{s}\right.$; $p<0.001)$ and $2012\left(19.5 \pm 2.6 \mathrm{~m}^{3} / \mathrm{s} ; p<0.001\right.$; Table 1$)$. No significant differences were observed between 2010 and 2012 in the LSWM $(p=0.113)$. A similar trend was observed in the OR, where mean discharge during the study period (June 26-August 27) was 3.4 times greater in $2011\left(9.1 \pm 0.9 \mathrm{~m}^{3} / \mathrm{s}\right)$ than in $2010\left(2.7 \pm 0.3 \mathrm{~m}^{3} / \mathrm{s}\right.$; $p<0.001)$, and 2.4 times greater in 2012 than in $2010\left(6.6 \pm 1.6 \mathrm{~m}^{3} / \mathrm{s} ; p=0.031\right.$; Table 1). Mean summer discharge (MSD) from 2010 to 2012 (interannual) in the LSWM River was $21.8 \pm 1.3 \mathrm{~m}^{3} / \mathrm{s}$, compared to $6.1 \pm 0.7 \mathrm{~m}^{3} / \mathrm{s}$ in the OR (Table 1; Figure 3). Intra-annual MSD, expressed as a percentage MSD for the study period, that is 2010-2012, was significantly different between rivers in 2010 (\% $\mathrm{MSD}_{\mathrm{LSWM}}=62.2$ and $\left.\% \mathrm{MSD}_{\mathrm{OR}}=43.9 ; t_{103}=2.8, p=0.006\right)$, but not in $2011(\%$ $\mathrm{MSD}_{\mathrm{LSWM}}=147.7$ and $\left.\% \mathrm{MSD}_{\mathrm{OR}}=148.2 ; t_{110}=0.1, p=0.979\right)$, or $2012(\%$ $\mathrm{MSD}_{\mathrm{LSWM}}=89.6$ and $\left.\% \mathrm{MSD}_{\mathrm{OR}}=107.7, t_{83}=0.7, p=0.499\right)$.

\subsection{Aggregation occurrence}

\subsubsection{Little Southwest Miramichi River}

Thermally challenging conditions exceeding $23^{\circ} \mathrm{C}$ occurred in the LSWM when discharge was predominantly $<67.5 \%$ of the interannual MSD, but were attained throughout a range of $28.7 \%-143 \%$ interannual MSD. During the study period, flows conducive to the development of thermal stress $\left(>23^{\circ} \mathrm{C}\right)$ in juvenile salmon were observed $98.4 \%$ of the time in $2010,64.5 \%$ in 2011 and $88.7 \%$ 2012. Mean time of diel $T_{\max }$ throughout the study period occurred at 17:11 $\mathrm{hr} \pm 55$ min (mean $\pm S D$; 
Figure 4a). Aggregations occurred on 11 days throughout all years; however, $T_{\text {onset }}$ occurred on 9 days due to persisting aggregations in 2010 (Table 1). In this year, aggregations occurred in the LSWM on four consecutive days (July 6-9; $T_{\max }=28.0$ $30.1^{\circ} \mathrm{C}$; Figure 2). Aggregations that occurred on July 6 dispersed late day, however, those that began on July 7 remained intact in all refuges until late day July 9. As a result, only two onset of aggregation temperatures were observed for this year, $T_{\text {onset }}=27.3$ and $27.4^{\circ} \mathrm{C}$ (Table 2; Figure 2). No aggregations were observed in 2011 $\left(T_{\max } \mathrm{LSWM}=25.5^{\circ} \mathrm{C}\right)$. In 2012, aggregations occurred on July 31, August 3-8 and August 28, with $T_{\text {onset }}$ and $T_{\max }$ ranging from $26.1-28.1^{\circ} \mathrm{C}$ and $26.8-28.8^{\circ} \mathrm{C}$ respectively (Table 2; Figure 2). Mean time of day for $T_{\text {onset }}$ was 15:08 hr and all aggregations occurred when discharge was $\leq 51 \%$ of MSD $\left(<11.1 \mathrm{~m}^{3} / \mathrm{s}\right.$; Figure 3$)$. 

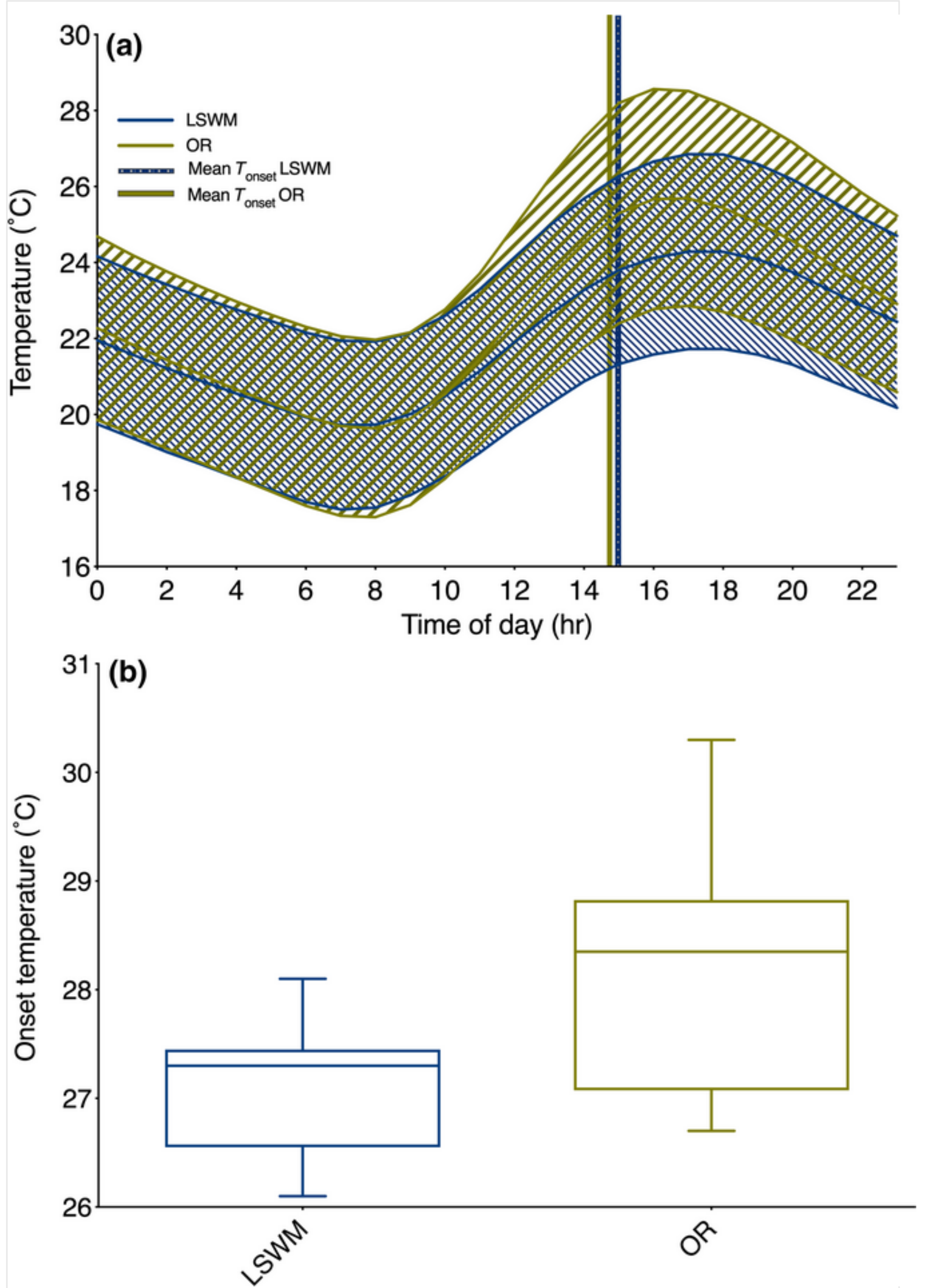

Fig. 4 Aggregation metrics depicting (a) mean hourly temperature for June 27-August 8 for 2010 and 2012, in the Little Southwest Miramichi River (LSWM) and the Ouelle River (OR). Shaded areas represent the standard deviation of the mean. Bars indicate mean time of onset of aggregation $\left(T_{\text {onset }}\right)$ in each river. Area under the curve (AUC) 
was used to determine cumulative differences in diel thermal patterning; (b) boxplot of pooled $T_{\text {onset }}$ for the LSWM and the OR from 2010 and 2012. Onset of aggregation temperature was significantly greater in the OR (Mann-Whitney $U$ test, $U=32.5$, $p=0.049)$

Table 2

Aggregation characteristics of the Little Southwest Miramichi River (LSWM) and the Ouelle River (OR) from 2010 to 2012. Data were collected from June 27 to August 26 in all years. No aggregations occurred in 2011 in either river

\begin{tabular}{|l|l|l|l|l|}
\hline $\begin{array}{l}\text { Aggregation } \\
\text { date }\end{array}$ & River & $\begin{array}{l}\text { Onset temp } \\
\left({ }^{\circ} \mathbf{C}\right)\end{array}$ & $\begin{array}{l}\text { Time of day } \\
(\mathbf{h r})\end{array}$ & $\begin{array}{l}\text { Daily maximum } \\
\text { temperature }\left({ }^{\circ} \mathbf{C}\right)\end{array}$ \\
\hline 2010 & LSWM & 27.3 & $15: 51$ & 28.0 \\
\hline July 6 & LSWM & 27.4 & $12: 15$ & 29.8 \\
\hline July $7^{\text {a }}$ & OR & 30.3 & $17: 00$ & 30.6 \\
\hline July 12 & OR & 26.7 & $12: 50$ & 28.6 \\
\hline July 14 & OR & 28.9 & $15: 45$ & 28.9 \\
\hline July 15 & OR & 27.0 & $15: 30$ & 27.1 \\
\hline August 4 & OR & 28.6 & $18: 34$ & 28.6 \\
\hline August 5 & & & $15: 45$ & 29.0 \\
\hline 2012 & OR & 28.1 & $13: 02$ & 27.5 \\
\hline July 15 & OR & 27.2 & $14: 48$ & 27.3 \\
\hline July 16 & OR & 27.3 & $15: 09$ & 27.1 \\
\hline July 21 & OR & 27.1 & $12: 59$ & 28.7 \\
\hline July 22 & OR & 28.5 & $13: 42$ & 29.5 \\
\hline July 27 & OR & 28.8 & $17: 30$ & 28.7 \\
\hline July 30 & LSWM & 28.1 & $13: 16$ & 29.8 \\
\hline July 31 & OR & 28.6 & $16: 46$ & 30.5 \\
\hline August 1 & OR & 28.8 & $16: 02$ & 27.3 \\
\hline August 2 & LSWM & 26.9 & $14: 30$ & 28.8 \\
\hline August 3 & LSWM & 26.4 & $15: 20$ & 28.6 \\
\hline August 4 & LSWM & 27.3 & $13: 34$ & 29.3 \\
\hline August 5 & OR & 29.2 & $15: 23$ & 28.2 \\
\hline August 5 & LSWM & 27.5 & \multicolumn{1}{l|}{} \\
\hline August 6 & & & \\
\hline
\end{tabular}




\begin{tabular}{|l|l|l|l|l|}
\hline August 7 & LSWM & 26.7 & $14: 25$ & 28.6 \\
\hline August 8 & LSWM & 26.1 & $14: 55$ & 26.8 \\
\hline
\end{tabular}

${ }^{a}$ Aggregations beginning on this day remained in place for 48+ consecutive hours, disassembling 9 July 2010 .

\subsubsection{Ouelle River}

In the OR, discharge conditions allowing for temperature to exceed $23^{\circ} \mathrm{C}$ were reached when flow was predominantly $<47.2 \%$ of the interannual MSD (range $=6.3 \%-357.4 \%)$. Similarly, flows where thermal stress might occur $\left(>23^{\circ} \mathrm{C}\right)$ were observed $98.4 \%$ of the time in $2010,75.8 \%$ in 2011 and $83.9 \%$ in 2012 . Mean time of diel $T_{\max }$ throughout the study period occurred at 16:00 $\mathrm{hr} \pm 51 \mathrm{~min}$ (mean $\pm S D$; Figure $4 \mathrm{a}$ ). The OR exhibited aggregations on 14 occasions, all when discharge was $\leq 57 \%$ of MSD $\left(<3.5 \mathrm{~m}^{3} / \mathrm{s}\right.$; Figure 3$)$. Aggregations occurred in the OR on five days in 2010, that is three days in July (July 12, 14 and 15; $T_{\text {onset }}=26.7-$ $30.3^{\circ} \mathrm{C} ; T_{\max }=28.6-30.6^{\circ} \mathrm{C}$; Table 2) and two consecutive days in August (August 4$5 ; T_{\text {onset }}=27.0-28.6^{\circ} \mathrm{C} ; T_{\max }=27.1-28.6^{\circ} \mathrm{C}$; Table 2; Figure 2). As in the LSWM, no aggregations were observed in the OR in 2011, despite maximum water temperatures of $28.2^{\circ} \mathrm{C}$. In 2012 , aggregations were observed on nine occasions, six occasions in July (15-16, 21-22, 27 and 30) and three occasions in August (1-2 and 5) when $T_{\text {onset }}$ ranged from 26.7 to $29.2^{\circ} \mathrm{C}$, and $T_{\max }$ ranged from 27.1 to $30.5^{\circ} \mathrm{C}$ (Table 2). Mean time of day for $T_{\text {onset }}$ was 14:54 hr in the OR (Figure 4a).

\subsection{Comparison and statistical analyses of LSWM versus OR}

In years containing aggregations $(2010 \& 2012)$, the area under the curve between rivers was significantly different (mean $\pm S D ; \mathrm{AUC}_{\mathrm{LSWM}}=496.4 \pm 58.9$, $\mathrm{AUC}_{\mathrm{OR}}=508.8 \pm 63.3 ; t_{85}=3.3, p=0.001$; Figure 4a). A significant difference was observed for both $T_{\text {mean }}$ and $T_{\max }$ on aggregation days in the LSWM versus days without aggregations leading up to the event $(F=29.0, p<0.001 \& F=20.2$, $p<0.001$ respectively). In the OR, no significant difference was found in $T_{\text {mean }}$ between aggregation and the preceding days $(F=2.4, p=0.136)$; however, there was a significant difference in $T_{\max }$ for the same period $(F=8.1, p=0.008)$. When years were pooled, $T_{\text {mean }}$ and $T_{\max }$ on aggregation days did not differ significantly between rivers $\left(F=3.1, p=0.093\right.$ and $F=0.1, p=0.707$ respectively). Median $T_{\text {onset }}$ between the LSWM and the OR, $27.3^{\circ} \mathrm{C}$ and $28.3^{\circ} \mathrm{C}$, respectively, varied significantly (MannWhitney $U=32.5 ; \mathrm{n}_{\mathrm{LSWM}}=9, \mathrm{n}_{\mathrm{OR}}=14 ; p=0.049$; Figure $4 \mathrm{~b}$ ). Time of day when aggregations occurred was earlier in the OR than the LSWM but was not found to differ significantly (mean $\pm S D=14: 54 \mathrm{hr} \pm 105.6 \mathrm{~min}, 15: 08 \mathrm{hr} \pm 85.7 \mathrm{~min}$ respectively; $t_{21}=0.72 ; p=0.562$; Figure $4 \mathrm{a}$; Table 2 ). Logistic regression coefficients were determined to be 1.432 for both rivers, while the intercept varied -35.909 and -40.875 for the LSWM and the OR respectively (Figure 5). Based on the logistic regression curve, $\mathrm{P}_{50}$ values (the temperature at which there is a $50 \%$ likelihood of an aggregation response) were $27.4^{\circ} \mathrm{C}$ and $28.9^{\circ} \mathrm{C}$ in the LSWM and the OR respectively. McFadden's pseudo- $\mathrm{R}^{2}$ values were 0.65 for the LSWM and 0.61 for the OR (Figure 5). 


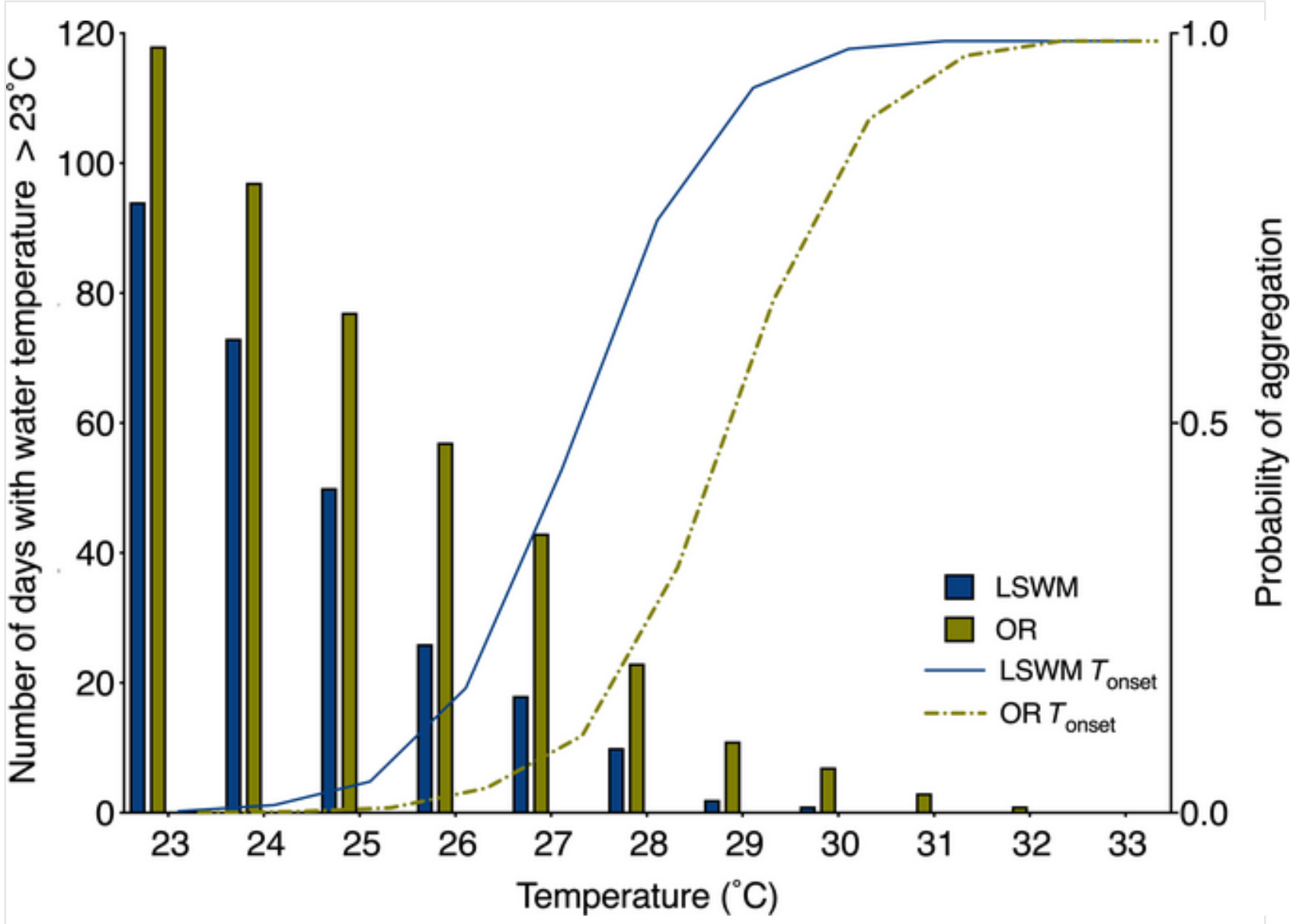

Fig. 5 Number of days with thermally challenging water temperatures $\left(>23^{\circ} \mathrm{C}\right)$ within the Little Southwest Miramichi River (LSWM) and the Ouelle River (OR) rivers throughout the 2010 and 2012 summer periods. The logistic regression curves for $T_{\text {onset }}$ show the probability of an aggregation event as a function of hours exceeding given temperatures in thermally stressful years (2010 and 2012)

\section{DISCUSSION}

Prevailing meteorological conditions in eastern Canada meant that the LSWM and the OR exhibited broadly similar thermal and discharge trends over the period of 20102012. The summers of 2010 and 2012 could be characterised as being relatively hot with low flow in both the Little Southwest Miramichi River and the Ouelle River. By contrast, the summer of 2011 saw comparatively greater rainfall resulting in higher than average flow and a lower mean water temperature. Elevated water temperatures and low summer flows are intrinsically linked (Wetzel, 2001). Aggregations occurred when main-stem discharge was well below MSD in their respective rivers but required a significant increase in water temperature for behavioural thermoregulation to occur. It is worth noting that discharge alone was not a viable predictor of aggregation occurrence, and thus, the observation of a low summer flow is a requirement, a precursor, among other environmental conditions that promote behavioural thermoregulation.

We predicted that the environmental conditions required to induce a thermal aggregation in juvenile Atlantic salmon would be similar between the two rivers. We established that the LSWM and OR had significantly different thermal regimes, with the OR experiencing physiologically stressful temperatures throughout a greater 
proportion of summer months compared to the LSWM. Contrary to our prediction, the behavioural thermoregulation response occurred at increased temperatures in the OR in comparison with the LSWM (median $T_{\text {onset }}=28.3^{\circ} \mathrm{C}$ and $27.3^{\circ} \mathrm{C}$ respectively; $p=0.049$ ), and this notion is further supported by observed differences in logistic regression intercepts and the observed differences in $\mathrm{P}_{50}$ values. Interestingly, the model coefficient was uniform across rivers (1.432), indicating a similar aggregation response despite differences in initiation temperature. These results may suggest a link between delayed aggregation responses in warmer, more thermally dynamic rivers. In 2011, water temperatures in the $\mathrm{LSWM}$ did not exceed $25.5^{\circ} \mathrm{C}$, whereas water temperatures in the OR surpassed the mean $T_{\text {onset }}$ of the LSWM on three occasions $\left(27.3-28.2^{\circ} \mathrm{C}\right)$ without an aggregation event. It is possible that the occurrence of an aggregation is tightly linked to the temperature experienced by the fish in the days and/or weeks leading up to the event (Frechette, Dugdale, Dodson, \& Bergeron, 2018). For example, in 2010 the mean $T_{\max }$ for the week prior to the first aggregation in the LSWM was $20.7^{\circ} \mathrm{C}$, allowing for a large jump in $T_{\max }$ on the first day of an event $\left(T_{\max }=28.0^{\circ} \mathrm{C}, T_{\text {onset }}=27.3^{\circ} \mathrm{C}\right)$. In 2012 , the thermal pattern suggested a different trigger for the aggregation response. Mean $T_{\max }$ on the week leading up to the first aggregation in the LSWM was $25.4^{\circ} \mathrm{C}$, but overall water temperatures had an increasing trend in diel $T_{\max }$ over the 30 days preceding this event (July $1=22.2^{\circ} \mathrm{C}$, July $29=25.9^{\circ} \mathrm{C}$; mean 30 -day $T_{\max }=23.8^{\circ} \mathrm{C}$ ), possibly indicative of a cumulative effect of warming temperatures driving the aggregation response. In 2011, temperatures in the OR did not show any major warming or cooling trend (mean $T_{\max } 30$ days prior $=24.1^{\circ} \mathrm{C}$; mean $T_{\max }$ week prior $=25.5^{\circ} \mathrm{C}$ ). This result may indicate that fish exposed to moderate thermal patterns, such as that in the OR in 2011 may have the ability to acclimate to the specific thermal condition experienced, resulting in a lack of behavioural thermoregulation on stressful days (within reason). In 2012, water temperature in the OR exceeded $T_{\text {onset }}$ of the LSWM on as many as six occasions without a PIT detected aggregation, whereas this occurred only three times in the LSWM. The results of this study suggest that juvenile salmon behaviour, in the face of high temperatures, is affected by preceding local environmental conditions. Our observations may imply an underlying physiological plasticity and points to the influence thermal exposure has on the behavioural thermoregulation response, despite a species-wide innate physiological "concrete ceiling" (Sandblom et al., 2016).

The implication of preconditioning in a natural environment remains a topic of much interest. An emerging body of literature suggests that when identically reared in a "common garden," there are minimal physiological differences in thermal optima for growth (Jonsson et al., 2001) and tolerance between salmonid populations from varying latitudinal and thermal profiles (Anttila et al., 2014; Elliott \& Elliott, 2010; Lyytikäinen, Koskela, \& Rissanen, 1997). Of further interest, evidence exists that indicates the ability of salmonids to acclimate to warmer thermal environments. Chen et al. (2015) found that rainbow trout (Oncorhynchus mykiss Walbaum) exposed to increased temperatures underwent selection pressure that reduced phenotypic variability allowing for an increased thermal tolerance (measured by aerobic scope and maximum heart rate) after 19 generations. Similarly, Narum, Campbell, Meyer, Miller, and Hardy (2013) and Chen, Farrell, Matala, Hoffman, and Narum (2018) found a localised adaptive response (heat shock and temperature tolerance for maximum heart rate) in redband trout (Oncorhynchus mykiss gairderi) of the 
Columbia River, where natural segregation of montane (cool water) and desert (warm water) populations has occurred. These results suggest that genetic selection for habitat (i.e. a localised physiological acclimation response) is possible given ample segregation and vast ecological timescales (Narum, Campbell, Kozfkay, \& Meyer, 2010).

Despite some discrepancies in opinion on the role of geographic origin in the intraspecific physiological response, it is commonly accepted that acute thermal tolerance in salmonids is inherently plastic and dependent on thermal exposure (Corey, Linnansaari, Cunjak, \& Currie, 2017; Konecki, Woody, \& Quinn, 1995; Lyytikäinen et al., 1997; Muñoz, Farrell, Heath, \& Neff, 2015). The variable onset of behavioural thermoregulation between the LSWM and the OR may indicate a threshold of behavioural thermoregulation specific to particular environmental conditions (preconditioning). This insinuates that the behavioural response in itself might be plastic, just as the preconditioning/thermal history has strong implications on the upper incipient lethal temperatures for many salmonid species (see: Anttila et al., 2014; Chen et al., 2018; Eliason et al., 2011; Farrell et al., 2008; Narum et al., 2013; Sandblom et al., 2016). Some evidence exists for this, as some alterations to behaviour due to climate change have been previously documented. Alterations to phenology and the timing of key lifecycle events have been observed in Atlantic salmon smolts (Crozier \& Hutchings, 2013) alongside sockeye (Oncorhynchus nerka) and pink (Oncorhynchus gorbuscha) salmon adults (Crozier, Scheuerell, \& Zabel, 2011; Kovach, Gharrett, \& Tallmon, 2012). These behavioural alterations to exploit habitat thermo-heterogeneity may play a pivotal role in population resilience to the effects of climate warming (Crozier et al., 2011; Mantua, Crozier, Reed, Schindler, \& Waples, 2015), alongside known physiological effects. With some indication that thermal cardiac capacity in salmonids (Muñoz et al., 2015), and temperature at death in mosquitofish, Gambusia holbrooki (Meffe, Weeks, Mulvey, \& Kandl, 1995); killifish, Heterandria formosa (Doyle, Leberg, \& Klerks, 2011); and brook trout, Salvelinus fontinalis (Stitt et al., 2014), are heritable traits, it is possible a local genetic component may act selectively to maximise thermal tolerance in stressful environments (Dionne, Caron, Dodson, \& Bernatchez, 2008). Although plasticity and adaptation may occur, any dramatic alteration to the current climate could run the risk of trait selection and population bottlenecking, possibly contributing to an overall reduction in genetic variation (Doyle et al., 2011; Falconer \& Mackay, 1996).

Salmon have a limited capacity to use phenotypic plasticity and genetic predisposition to acclimate to a warmer environment (Baroudy \& Elliott, 1994; Elliott, 1991; Muñoz et al., 2015). Phenotypic plasticity and genotypic adaptation occur due to varying selection pressures, and the degree to which these processes manifest will largely impact salmonid survival in a changing climate. Notably, understanding how fishes exploit habitat heterogeneity as thermal "safeguards" is an important concept across landscapes and large geographic areas. Here, we propose that thermal physiological thresholds do not correspond with aggregation occurrence, and they might not apply universally across riverscapes. We suggest a degree of plasticity in the behavioural response to a physiological threshold similar to the phenotypic plasticity in the thermal tolerance of salmonids. It is likely that this intricate relationship between physiology and behaviour is intimately tied to localised thermal history and preconditioning, be it system, river or reach specific. Our study alludes to behavioural plasticity in juvenile Atlantic salmon based on thermal regime, an indirect indicator 
of the importance of thermal heterogeneity in rivers. With predictions of further increases in water temperatures in coming decades for both the OR (Jeong, Daigle, \& St.-Hilaire, A., 2013) and the LSWM (Caissie, 2013; Caissie, El-Jabi, \& Turkkan, 2014) watersheds, our findings may argue for a change in management practices, focusing on a narrow, river-specific approach based on local environmental conditions. As the use of coolwater resources remains a universal phenomenon despite a possible localised aggregation response, it is critical that thermoheterogeneity remains a prominent habitat feature across riverscapes, whether natural, or created by restoration activities (Kurylyk, MacQuarrie, Linnansaari, Cunjak, \& Curry, 2015). With this, it is important that conservation efforts make a concerted effort to incorporate and develop river-specific, complex thermal habitat structures that allow for the necessary thermal heterogeneity to buffer the ever-increasing threat of extreme thermal events to cold water species.

\section{ACKNOWLEDGEMENTS}

This work was primarily supported by an NSERC Collaborative Research and Development grant CRDJ 379745-08 in association with the Ouranos and HydroQuébec consortium on regional climatology and adaptation to climate change. This paper is Contribution No. 136 of the Catamaran Brook Habitat Research Project. The authors would like to thank Mat FitzGerald, Catherine Desjardins, Sarah Lehnert, Antóin O'Sullivan, Jan Franssen, Clément Clerc, Carole-Anne Gillis, Jean-Baptiste Torterotot, Marc-André Pouliot, Francis Bérubé, André Boivin, Adrien Lepoutre and Fraser McLaughlin for their support and dedication throughout the data collection process. The authors would also like to acknowledge the anonymous reviewers for their constructive criticism that helped to greatly improve the quality of this written manuscript.

\section{AUTHORS' CONTRIBUTION}

T.L., M.L., R.A.C. and N.B. conceived and designed the investigation. S.D., E.C., J.F.G. and T.L. performed field and/or laboratory work. E.C. and S.D. analysed the data. T.L. and N.B. contributed materials, and/or tools for analysis. E.C. wrote the manuscript.

AQ3

\section{Funding Information}

\begin{tabular}{|l|l|}
\hline $\begin{array}{l}\text { Natural Sciences and } \\
\text { Engineering Research } \\
\text { Council of Canada }\end{array}$ & CRDJ 379745-08 \\
\hline
\end{tabular}

REFERENCES

Amiro, P. G. (1983). Aerial photographic measurement of Atlantic salmon habitat of the Miramichi River, New Brunswick. Canadian Atlantic Fisheries Scientific Advisory Committee Research Document, 83/74. 31 p.

Anttila, K., Couturier, C. S., Øverli, Ø., Johnsen, A., Marthinsen, G., Nilsson, G. E., $\&$ Farrell, A. P. (2014). Atlantic salmon show capability for cardiac acclimation to 
warm temperatures. Nature Communications, 5, 4252. https://doi.org/10.1038/ncomms5252

Armstrong, J. B., Ward, E. J., Schindler, D. E., \& Lisi, P. J. (2016). Adaptive capacity at the northern front: Sockeye salmon behaviourally thermoregulate during novel exposure to warm temperatures. Conservation Physiology,

AQ4 https://doi.org/10.1093/conphys/cow039

Baroudy, E., \& Elliott, J. M. (1994). The critical thermal limits for juvenile Arctic charr Salvalinus alpinus. The Journal of Fish Biology, 45, 1041-1053.

Breau, C., Cunjak, R. A., \& Bremset, G. (2007). Age-specific aggregation of wild juvenile Atlantic salmon Salmo salar at cool water sources during high temperature events. Journal of Fish Biology, 71, 1179-1191. https://doi.org/10.1111/j.10958649.2007.01591.x

Breau, C., Cunjak, R. A., \& Peake, S. J. (2011). Behaviour during elevated water temperatures: Can physiology explain movement of juvenile Atlantic salmon to cool water? Journal of Animal Ecology, 80, 844-853. https://doi.org/10.1111/j.13652656.2011.01828.x

Brodeur, N. N., Hébert, C., Caissie, D., \& Breau, C. (2015). Predicting stream temperatures under a climate change scenario: impacts on critical temperatures for Atlantic salmon (Salmo salar). Canadian Technical Report on Fisheries and Aquatic Sciences, 3118: ix +44 p.

Brown, R. S., Stanislawski, S. S., \& Mackay, W. C. (1993). Effects of frazil ice on fish. In T. D. Prowse (Eds.), Proceedings of the Workshop on Environmental Aspects of River Ice. National Hydrology Research Institute, Saskatoon, Canada: NHRI Symposium Series, 12, 261-278.

Caissie, D., Breau, C., Hayward, J., \& Cameron, P. (2012). Water temperature characteristics within the Miramichi and Restigouche rivers. Canadian Science Advisory Secretariat Research Document, 2012/nnn. vi + xx p.

Caissie, D. (2006). The thermal regime of rivers: A review. Freshwater Biology, 51, 1389-1406. https://doi.org/10.1111/j.1365-2427.2006.01597.x

Caissie, D. (2013). Impact of climate change on water temperatures for selected rivers in New Brunswick and potential implications on Atlantic salmon. Ch. 13 (p. In: Aspects of climate change in the Northwest Atlantic off Canada [J. W. Loder, G. Han, P. S. Galbraith, J. Chassé, \& A. van der Baaren (Eds.)]. Canadian Technical Report of Fisheries and Aquatic Sciences, 3045, 183-190.

Caissie, D., El-Jabi, N., \& Turkkan, N. (2014). Stream water temperature modelling under climate change scenarios B1 \& A2. Canadian Technical Report on Fisheries and Aquatic Science, 3106. Ottawa: Fisheries and Oceans Canada. 
Caissie, D., Satish, M. G., \& El-Jabi, N. (2007). Predicting water temperatures using a deterministic model: Application on Miramichi River catchments (New Brunswick, Canada). Journal of Hydrology, 336, 303-315.

https://doi.org/10.1016/j.jhydrol.2007.01.008

Chen, Z., Farrell, A. P., Matala, A., Hoffman, N., \& Narum, S. R. (2018).

Physiological and genomic signatures of evolutionary thermal adaptation in redband trout from extreme climates. Evolutionary Applications, 11, 1686-1699.

https://doi.org/10.1111/eva.12672

Chen, Z., Snow, M., Lawrence, C. S., Church, A. R., Narum, S. R., Devlin, R. H., \& Farrell, A. P. (2015). Selection for upper thermal tolerance in rainbow trout (Oncorhynchus mykiss Walbaum). The Journal of Experimental Biology, 218, 803812. https://doi.org/10.1242/jeb.113993

Comte, L., Buisson, L., Daufresne, M., \& Grenouillet, G. (2013). Climate-induced changes in the distribution of freshwater fish: Observed and predicted trends. Freshwater Biology, 58, 625-639. https://doi.org/10.1111/fwb.12081

Corey, E., Linnansaari, T., Cunjak, R. A., \& Currie, S. (2017). Physiological effect of environmentally relevant, multi-day thermal stress on wild juvenile Atlantic salmon (Salmo salar). Conservation Physiology, https://doi.org/10.1093/conphys/cox014 AQ5

Crozier, L. G., \& Hutchings, J. A. (2013). Plastic and evolutionary responses to climate change in fish. Evolutionary Applications, 7, 68-87.

https://doi.org/10.1111/eva.12135

Crozier, L. G., Scheuerell, M. D., \& Zabel, R. W. (2011). Using time series analysis to characterize evolutionary and plastic responses to environmental change a case study of a shift toward earlier migration date in sockeye salmon. The American Naturalist, 178, 755-773. https://doi.org/10.1086/662669

Cunjak, R. A., Caissie, D., El-Jabi, N., Hardie, P., Conlon, J. H., Pollock, T. L., ... Komadina-Douthwright, S. (1993). The Catamaran Brook (New Brunswick) habitat research project: Biological, physical and chemical conditions (1990-1992). Canadian Technical Report of Fisheries and Aquatic Sciences, no. 1914.

Cunjak, R. A., Linnansaari, T., \& Caissie, D. (2013). The complex interaction of ecology and hydrology in a small catchment: A salmon's perspective. Hydrological Processes, 27, 741-749.

Cunjak, R. A., \& Power, G. (1986). Winter habitat utilization by stream resident brook trout (Salvelinus fontinalis) and Brown Trout (Salmo trutta). Canadian Journal of Fisheries and Aquatic Sciences, 43, 1970-1981.

Cunjak, R. A., Roussel, J.-M., Gray, M. A., Dietrich, J. P., Cartwright, K. R., Munkittrick, K. R., \& Jardine, T. D. (2005). Using stable isotope analysis with telemetry or mark-recapture data to identify fish movement and foraging. Oecologia, 144, 636-646. 
R Development Core Team (2016). R: A language and environment for statistical computing. R Foundations for Statistical Computing, Vienna, Austria. Retrieved from http://R-project.org/

DFO (2015). Update of stock status of Atlantic salmon (Salmo salar) in DFO Gulf Region (New Brunswick Salmon Fishing Areas 15 and 16) for 2014. Department of Fisheries and Oceans Canadian Science Advisory Secretariat Science Report, 2015/008.

Dionne, M., Caron, F., Dodson, J. J., \& Bernatchez, L. (2008). Landscape genetics and hierarchical genetic structure in Atlantic salmon: The interaction of gene flow and local adaptation. Molecular Ecology, 17, 2382-2396.

Doyle, C. M., Leberg, P. L., \& Klerks, P. L. (2011). Heritability of heat tolerance in a small livebearing fish, Heterandria formosa. Ecotoxicology, 20, 535-542.

Dugdale, S. J., Franssen, J., Corey, E., Bergeron, N. E., Lapointe, M., \& Cunjak, R. A. (2016). Main stem movement of Atlantic salmon parr in response to high river temperature. Ecology of Freshwater Fish, 25, 429-445.

https://doi.org/10.1111/eff.12224

Eliason, E. J., Clark, T. D., Hague, M. J., Hanson, L. M., Gallagher, Z. S., Jefferies, K. M., ... Farrell, A. P. (2011). Differences in thermal tolerance among sockeye salmon populations. Science, 332, 109-112.

Elliott, J. M. (1991). Tolerance and resistance to thermal stress in juvenile Atlantic salmon, Salmo salar. Freshwater Biology, 25, 61-70. https://doi.org/10.1111/j.13652427.1991.tb00473.x

Elliott, J. M., \& Elliott, J. A. (2010). Temperature requirements of Atlantic salmon Salmo salar, brown trout Salmo trutta and Arctic charr Salvelinus alpinus: Predicting the effects of climate change. Journal of Fish Biology, 77, 1793-1817.

Elliott, J. M., \& Hurley, A. (1997). A functional model for maximum growth of Atlantic Salmon parr, Salmo salar, from two populations in northwest England. Functional Ecology, 11, 592-603.

Falconer, D. S., \& Mackay, T. F. C. (1996). Introduction to quantitative genetics (4th ed.). Essex, UK: Longman Publishing.

Farrell, A. P., Hinch, S. G., Cooke, S. J., Patterson, D. A., Crossin, G. T., Lapointe, M., \& Mathes, M. T. (2008). Pacific salmon in hot water: Applying aerobic scope models and biotelemetry to predict the success of spawning migrations. Physiological and Biochemical Zoology, 81, 697-708. https://doi.org/10.1086/592057

Frechette, D. M., Dugdale, S. J., Dodson, J. J., \& Bergeron, N. E. (2018). Understanding summertime thermal refuge use by adult Atlantic salmon using remote sensing, river temperature monitoring, and acoustic telemetry. Canadian Journal of 
Fisheries and Aquatic Sciences, 75, 1999-2010. https://doi.org/10.1139/cjfas-20170422

Gendron, J.-F. (2013). Physical controls on summer thermal refuges for salmonids in two gravel-cobble salmon rivers with contrasting thermal regimes: The Ouelle and Ste-Marguerite Rivers. Unpublished MSc thesis, McGill University, Montréal, Canada.

Gibbons, J. W., \& Sharitz, R. R. (1981). Thermal ecology: Environmental teachings of a nuclear reactor site. BioScience, 31, 293-298. https://doi.org/10.2307/1308146

Gibson, R. J. (1966). Some factors influencing the distribution of brook trout and young Atlantic salmon. Journal of the Fisheries Research Board of Canada, 23, 19771980.

Grande, M., \& Andersen, S. (1991). Critical thermal maxima for young salmonids. Journal of Freshwater Ecology, 6, 275-279.

https://doi.org/10.1080/02705060.1991.9665304

Gries, G., Whalen, K. G., Juanes, F., \& Parrish, D. (1997). Nocturnal activity of juvenile Atlantic salmon (Salmo salar) in late summer: Evidence of diel activity partitioning. Canadian Journal of Fisheries and Aquatic Sciences, 54, 1408-1413. https://doi.org/10.1139/f97-046

Hebert, C., Caissie, D., Satish, M. G., \& El- Jabi, N. (2011). Stream temperature dynamics and corresponding heat fluxes within Miramichi river catchments (new Brunswick, Canada). Hydrological Processes, 25, 2439-2455.

IPCC (2014). Climate change 2014: Contribution of working groups I, II and III to the Fifth Assessment Report of the Intergovernmental Panel on Climate Change. In R. K. Pachauri \& L. A. Meyer (Eds.), IPCC Synthesis Report, (p. 151). Geneva, Switzerland.

Isaak, D. J., Young, M. K., Nagel, D. E., Horan, D. L., \& Groce, M. C. (2015). The cold-water climate shield: Delineating refugia for preserving salmonid fishes through the 21st century. Global Change Biology, 21, 2540-2553.

https://doi.org/10.1111/gcb.12879

Jeong, D. I., Daigle, A., \& St.-Hilaire, A. (2013). Development of a stochastic water temperature model and projections of future water temperature and extreme events in the Ouelle River basin, in Québec, Canada. River Research and Applications, 29, 805-821.

Johnson, D. H., Shrier, B. M., O’Neal, J. S., Knutzen, J. A., Augerot, X., O’Neil, T. A., \& Pearsons, T. N. (2007). Salmonid Field Protocols Handbook: Techniques for assessing status and trends in salmon and trout populations (p. 478). Bethesda, MD: American Fisheries Society. 
Jonsson, B . (1989). Life history and habitat use of Norwegian brown trout (Salmo trutta). Freshwater Biology, 21, 71-86. https://doi.org/10.1111/j.1365-

2427.1989.tb01349.x

Jonsson, B., Forseth, T., Jensen, A. J., \& Næsje, T. F. (2001). Thermal performance of juvenile Atlantic salmon, Salmo salar L. Functional Ecology, 15, 701-711. https://doi.org/10.1046/j.0269-8463.2001.00572.x

Jonsson, B., \& Jonsson, N. (2009). A review of the likely effects of climate change on anadromous Atlantic salmon Salmo salar and brown trout Salmo trutta, with particular reference to water temperature and flow. Journal of Fish Biology, 75, 2381-2447.

Kaya, C. M., Kaeding, L. R., \& Burkhalter, D. E. (1977). Use of a cold-water refuge by rainbow and brown trout in a geothermally heated stream. The Progressive Fish Culturist, 39, 37-38. https://doi.org/10.1577/1548-

8659(1977)39[37:UOACRB]2.0.CO;2

Konecki, J. T., Woody, C. A., \& Quinn, T. P. (1995). Critical thermal maxima of coho salmon (Oncorhynchus kisutch) fry under field and laboratory acclimation regimes. Canadian Journal of Zoology, 73, 993-996.

Kovach, R. P., Gharrett, A. J., \& Tallmon, D. A. (2012). Genetic change for earlier migration timing in a pink salmon population. Proceedings of the Royal Society B: Biological Sciences, 279, 3870-3878. https://doi.org/10.1098/rspb.2012.1158

Kurylyk, B. L., MacQuarrie, K. T. B., Linnansaari, T., Cunjak, R. A., \& Curry, R. A. (2015). Preserving, augmenting, and creating cold-water thermal refugia in rivers: Concepts derived from research on the Miramichi River, New Brunswick (Canada). Ecohydrology, 8, 1095-1108. https://doi.org/10.1002/eco.1566

Kurylyk, B. L., MacQuarrie, K. T. B., \& Voss, C. I. (2014). Climate change impacts on the temperature and magnitude of groundwater discharge from shallow, unconfined aquifers. Water Resource Research, 50, 3253-3274. https://doi.org/10.1002/2013WR014588

Linnansaari, T., \& Cunjak, R. A. (2007). The performance and efficacy of a twoperson operated portable PIT-antennae for monitoring spatial distribution of stream fish populations. River Research and Applications, 23, 559-564.

Linnansaari, T., Roussel, J.-M., Cunjak, R. A., \& Halleraker, J. H. (2007). Efficacy and accuracy of portable PIT-antennae when locating fish in ice-covered streams. Hydrobiologia, 582, 281-287. https://doi.org/10.1007/s10750-006-0546-9

Lund, S. G., Caissie, D., Cunjak, R. A., Vijayan, M. M., \& Tufts, B. L. (2002). The effects of environmental heat stress on heat-shock mRNA and protein expression in Miramichi Atlantic salmon (Salmo salar) parr. Canadian Journal of Fisheries and Aquatic Sciences, 59, 1553-1562. 
Lytle, D. A., \& Poff, N. L. (2004). Adaptation to natural flow regimes. Trends in Ecology \& Evolution, 19, 94-100. https://doi.org/10.1016/j.tree.2003.10.002

Lyytikäinen, T., Koskela, J., \& Rissanen, I. (1997). Thermal resistance and upper lethal temperatures of underyearling Lake Inari Arctic charr. Journal of Fish Biology, $51,515-525$.

Mantua, N., Crozier, L. G., Reed, T. E., Schindler, D. E., \& Waples, R. S. (2015). Response of chinook salmon to climate change. Nature Climate Change, 5, 613-615. https://doi.org/10.1038/nclimate2670

Meffe, G. K., Weeks, S. C., Mulvey, M., \& Kandl, K. L. (1995). Genetic differences in thermal tolerance of eastern mosquitofish (Gambusia holbrooki; Poeciliidae) from ambient and thermal ponds. Canadian Journal of Fisheries and Aquatic Sciences, 52, 2704-2711.

Mundahl, N. D. (1989). Seasonal and diel changes in thermal tolerance of the crayfish Orconectes rusticus, with evidence for behavioural thermoregulation. Journal of the North American Benthological Society, 8, 173-179.

Muñoz, N. J., Farrell, A. P., Heath, J. W., \& Neff, B. D. (2015). Adaptive potential of a Pacific salmon challenged by climate change. Nature Climate Change, 5, 163-166. https://doi.org/10.1038/nclimate2473

Narum, S. R., Campbell, N. R., Kozfkay, C. C., \& Meyer, K. A. (2010). Adaptation of redband trout in desert and montane environments. Molecular Ecology, 19, 46224637. https://doi.org/10.1111/j.1365-294X.2010.04839.x

Narum, S. R., Campbell, N. R., Meyer, K. A., Miller, M. R., \& Hardy, R. W. (2013). Thermal adaptation and acclimation of ectotherms from differing aquatic climates. Molecular Ecology, 22, 3090-3097. https://doi.org/10.1111/mec.12240

Peterson, J. T., \& Rabeni, C. F. (1996). Natural thermal refugia for temperate warmwater stream fishes. North American Journal of Fisheries Management, 16, 738-746. https://doi.org/10.1577/1548-8675(1996)016<0738:NTRFTW>2.3.CO;2

Puffer, M., Berg, O. K., Huusko, A., Vehanen, T., Forseth, T., \& Einum, S. (2015). Seasonal effects of hydropeaking on growth, energetics and movement of juvenile Atlantic salmon (Salmo salar). River Research and Applications, 31, 1101-1108.

Ruxton, G. D. (2006). The unequal variance $t-t e s t$ is an underused alternative to Student's t-test and the Mann-Whitney $U$ test. Behavioural Ecology, 17, 688-690. https://doi.org/10.1093/beheco/ark016

Sandblom, E., Clark, T. D., Gräns, A., Ekström, A., Brijs, J., Sundström, L. F., ... Jutfelt, F. (2016). Physiological constraints to climate warming in fish following principles of plastic floors and concrete ceilings. Nature Communications, 7, 11447. https://doi.org/10.1038/ncomms 11447 
Schlosser, I. J. (1991). Stream fish ecology: A landscape perspective. BioScience, 41, 704-712. https://doi.org/10.2307/1311765

Sigourney, D. B., Horton, G. E., Dubreuil, T. L., Varaday, A. M., \& Letcher, B. H. (2005). Electroshocking and PIT tagging of juvenile Atlantic salmon: Are there interactive effects on growth and survival? North American Journal of Fisheries Management, 25, 1016-1021. https://doi.org/10.1577/M04-075.1

Snucins, E. J., \& Gunn, J. M. (1995). Coping with a warm environment: Behavioural thermoregulation by lake trout. Transactions of the American Fisheries Society, 124, $118-123$.

Stitt, B. C., Burness, G., Burgomaster, K. A., Currie, S., McDermid, J. L., \& Wilson, C. C. (2014). Intraspecific variation in thermal tolerance and acclimation capacity in brook trout (Salvelinus fontinalis): Physiological implications for climate change. Physiological and Biochemical Zoology, 87, 15-29.

Swansburg, E., Chaput, G., Moore, D., Caissie, D., \& El-Jabi, N. (2002). Size variability of juvenile Atlantic salmon: Links to environmental conditions. Journal of Fish Biology, 61, 661-683. https://doi.org/10.1111/j.1095-8649.2002.tb00903.x

Thorpe, J. E., Morgan, R. I. G., Pretswell, D., \& Higgins, P. J. (1988). Movement rhythms in juvenile Atlantic salmon, Salmo salar L. Journal of Fish Biology, 33, 931-940. https://doi.org/10.1111/j.1095-8649.1988.tb05542.x

Torgersen, C. E., Price, D. M., Li, H. W., \& McIntosh, B. A. (1999). Multiscale thermal refugia and stream habitat association of chinook salmon in northeastern Oregon. Ecological Applications, 9, 301-319.

Wentworth, C. K. (1922). A scale of grade and class terms for clastic sediments. The Journal of Geology, 30, 377-392. https://doi.org/10.1086/622910

Wetzel, R. G. (2001). Limnology: Lake and river ecosystems (3rd ed., p. 1006). Oxford, UK: Academic Press Elsevier. 